\title{
Oral Focal Epithelial Hyperplasia: Report of Five Cases
}

\author{
Cristina Maria BORBOREMA-SANTOS ${ }^{1}$ \\ Maria Marta de CASTRO ${ }^{1}$ \\ Paulo José Benevides dos SANTOS ${ }^{1,2}$ \\ Sinésio TALHARI ${ }^{3}$ \\ Spartaco ASTOLFI-FILHO ${ }^{1}$
}

\author{
${ }^{1}$ Center of Multidisciplinary Support (CAM), Federal University of Amazonas (UFAM), Manaus, AM, Brazil \\ ${ }^{2}$ Amazonas State Foundation Center of Oncology Control (FCECON), Manaus, AM, Brazil \\ ${ }^{3}$ Amazonas State Foundation of Tropical Medicine (FMT-AM), Manaus, AM, Brazil
}

\begin{abstract}
Focal epithelial hyperplasia or Heck's disease is a rare contagious disease caused by human papillomavirus types 13 or 32 , initially described among Native American populations. This condition is characterized by the occurrence of multiple small papules or nodules in oral cavity, especially on labial and buccal mucosa and tongue. This report describes the diagnosis of focal epithelial hyperplasia in five Central Amazonian Indians who sought treatment at the Amazonas State Foundation of Tropical Medicine (FMT-AM), using clinical criteria, polymerase chain reaction (PCR) and DNA sequencing.
\end{abstract}

Key Words: focal epithelial hyperplasia, polymerase chain reaction, South American Indians.

\section{INTRODUTION}

Focal epithelial hyperplasia (FEH) or Heck's disease is a rare contagious disease caused by human papillomavirus that was first described in 1965 from the observation of isolated or multiple soft papular and nodular eruptions on the oral mucosa of Navajo Xavante Indian and Alaska Eskimo children (1). Focal epithelial hyperplasia was initially reported mostly among Native Americans, Eskimos and South Africans but has also been found in other ethnic groups. It is more frequent in younger age groups and sometimes has also a characteristic familial occurrence, which led to the suggestion that a genetic predisposition may contribute to the development of the disease (2).

FEH manifests on the mucosa as multiple or unique soft papules of whitish or normal color with a smooth surface and measuring 1 to $10 \mathrm{~mm}$ in diameter. The lesions are painless, tend to disappear spontaneously, and are predominantly found on the lower lip, buccal mucosa and tongue, and less often on the upper lip, gingiva and palate $(2,3)$.

The etiologic agent of FEH was first characterized in 1983 and was designated as HPV 13, which is related to HPV 6 and HPV 11 (4). Years later, another type of HPV was isolated from FEH and referred as HPV 32, which was also related to HPV 6 and HPV 13 (5). More recently, FEH was renamed as multifocal papillomavirus epithelial hyperplasia (MPVEH) (6).

This paper reports five typical cases of focal epithelial hyperplasia and demonstrates the association with HPV 13 through polymerase chain reaction (PCR) and sequencing of PCR products.

\section{CASE REPORT}

Five patients ( 3 male and 2 female, aged 3 to 17 years) from a Central Amazonian Indian community sought treatment at the Amazonas State Foundation of Tropical Medicine (FMT-AM) in Manaus (Brazil). They

Correspondence: Profa. Cristina Maria Borborema dos Santos, Centro de Apoio Multidisciplinar - Universidade Federal do Amazonas, Minicampus - Bloco G, Avenida General Rodrigo Otávio Jordão Ramos, 3.000, Bairro Aleixo, 69077-000 Manaus, AM. Tel: +55-92-36474230. Fax: +55-92-3647-4018. e-mail: crisantos@ufam.edu.br 
presented multiple soft papular whitish to normally colored mucosal lesions, predominantly located on the lower lip and buccal mucosa, but also affecting the upper lip and tongue mucosa (Fig. 1). Two of the patients were siblings. The lesions were asymptomatic and the only discomfort they caused was their presence itself. All lesions were classified as papular, according to Pilgard's criteria (7). The clinical diagnosis of FEH was straightforward, and main differential diagnosis included other lesions caused by HPV, especially condylomata acuminata. To confirm the diagnosis, superficial epithelial cells were collected from the lesions for molecular examination. To avoid unnecessary invasive techniques and discomfort to the patients, no histological examination or other types of tests were performed until the results of molecular analysis were obtained.

\section{PCR Analysis and DNA Sequencing}

Sample collection: cells from mucosal lesions were collected by the cytobrush technique, immersed in $400 \mu \mathrm{L}$ of TE buffer (Tris-HCl $10 \mathrm{mM} \mathrm{pH} 8.0$ and EDTA $1 \mathrm{mM}$ ) and stored at $-20^{\circ} \mathrm{C}$ until use (8).

Preparation of samples for PCR: samples were digested in a solution with $2 \%$ Tween $20,200 \mu \mathrm{g} / \mathrm{mL}$ of proteinase $\mathrm{K}$ in TE (Tris- $\mathrm{HCl} 10 \mathrm{mM} \mathrm{pH} 8.0$ and EDTA $1 \mathrm{mM}$ ), incubated at $55^{\circ} \mathrm{C}$ for $1 \mathrm{~h}$ and then at $95^{\circ} \mathrm{C}$ for $10 \mathrm{~min}$. The digested samples were maintained at $-20^{\circ} \mathrm{C}$ until use (8).

Amplification reaction: the universal primers MY09 and MY11 were used to amplify L1 region of HPV 450 bp fragments. Primer sequence was MY09 -

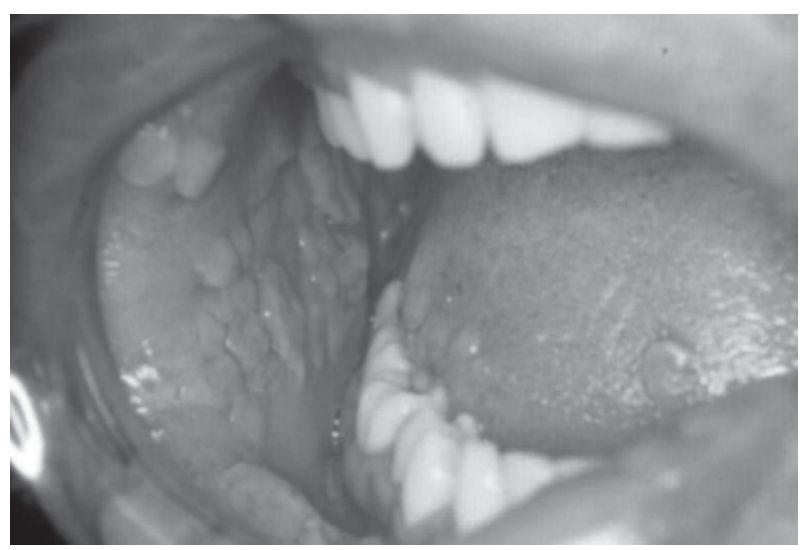

Figure 1. Focal epithelial hyperplasia in a 17 year-old male patient, with multiple papules on lip, buccal and tongue mucosa.
5'CGT CCM AAR GGA WAC TGA TC3' and MY11 5'GCM CAG GGW CAT AAY AAT GG3' (8).

PCR conditions: a typical reaction system containing a final volume of $50 \mu \mathrm{L}$ was composed of 5 $\mu \mathrm{L}$ DNA sample; $2.5 \mathrm{mM} \mathrm{MgCl2}, 0.25 \mathrm{mM}$ dNTP, 25 pmol of each primer MY09 and MY11, 4U Taq DNA polymerase, $50 \mathrm{mM} \mathrm{KCl}$ and $10 \mathrm{mM}$ Tris- $\mathrm{HCl}(\mathrm{pH} \mathrm{8.5)}$. PCR reactions were carried out using an Eppendorf Master Cycler Gradient thermocycler (Eppendorf Scientific, Inc., Westbury, NY, USA), according to the following protocol: $95^{\circ} \mathrm{C}$ for $2 \mathrm{~min}$ (Hot-Start), denaturation at $95^{\circ} \mathrm{C}$ for $1 \mathrm{~min}$, annealing at $55^{\circ} \mathrm{C}$ for $1 \mathrm{~min}$ and polymerization at $72^{\circ} \mathrm{C}$ for $1 \mathrm{~min}$ ( 35 cycles), followed by end extension at $72^{\circ} \mathrm{C}$ for $5 \mathrm{~min}$. The products were analyzed in $1.5 \%$ agarose gel electrophoresis.

\section{DNA Sequencing}

PCR products were purified using a MicroSpinTM S-400 column (Amersham Biosciences Corp., Piscataway, NJ, USA). The purified PCR products were used for sequencing following the protocol: $1 \mu \mathrm{L}$ of primer MY11 (upstream) 25 pmol, $4 \mu \mathrm{L}$ of mix Dynamic ET terminator cycle sequencing kit (Amersham Biosciences Corp.) and $5 \mu \mathrm{L}$ of purified PCR products. The sequencing reaction was carried out using the Eppendorf Master Cycler Gradient thermocycler (Eppendorf Scientific, Inc.), according to the following cycling profile: $25 \mathrm{~s}$ at $95^{\circ} \mathrm{C}$ (Hot-start), $15 \mathrm{~s}$ at $95^{\circ} \mathrm{C}$ for denaturation, $10 \mathrm{~s}$ at $50^{\circ} \mathrm{C}$ for annealing and extension at $60^{\circ} \mathrm{C}$ for $1 \mathrm{~min}(35 \mathrm{cycles})$. Finally, the sequencing products were precipitated with $0.1 \mathrm{~V}$ of ammonium acetate $7.5 \mathrm{M}$ and $4 \mathrm{~V}$ of ethanol absolute for analysis. The sequencing purified products were dissolved in 10 $\mu \mathrm{L}$ of Loading buffer $(70 \%$ formamide and $1 \mathrm{mM}$ EDTA).

The analysis of sequencing purified products were performed in the MegaBACE 1000 automated sequencing system (Amersham Biosciences Corp.) and then sequences were compared with GeneBank HPV sequences (www.ncbi.nlm.nih.gov) using FASTA sequences and BLAST program.

\section{RESULTS}

All samples were positive for HPV and showed 450 bp DNA fragments by electrophoresis on $1.5 \%$ 
agarose gel, corresponding to the HPV L1 capsid protein (Fig. 2)

The analysis of sequencing purified products with BLAST program showed $99 \%$ of similarity with HPV 13 (gi | 60295 | emb | X62843.1 |) (9).

\section{DISCUSSION}

Focal epithelial hyperplasia does not seem to be a diagnostic challenge as long as careful examination and description of the lesions are made and patient's medical history is comprehensively reviewed. Important data are those regarding communal way of life, with characteristic sharing of food, personal objects and lack of hygiene, which is typically observed among Brazilian Indian communities. The lesions themselves are also quite easily identifiable because of their multiplicity, small diameter of each isolated papule or nodule, soft consistence and typical intraoral topography. According to some authors, lesion predilection for lip, buccal and tongue mucosa is a sign of the infectious nature of the disease and is consistent with the patients' communal way of life (10).

The lesions have soft consistence and discreet size, being predominantly manifested as small-diameter flat papules rather than elevated nodules, which is a consequence of their typical histopathologic architecture. All alterations occur in the epithelial layer of the mucosa, with virtually no alteration in the underlying connective

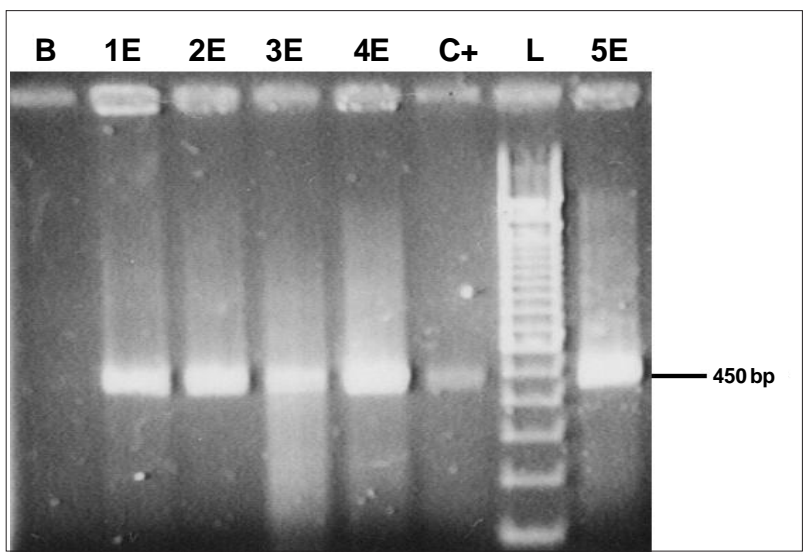

Figure 2. Agarose gel electrophoresis of PCR products obtained from smears of oral mucosa lesions. The fragment of $450 \mathrm{bp}$ corresponds to the amplification of L1 region of HPV viral capsid with consensus primers MY09 and MY11. L = Ladder 100pb GIBCO/BRL; $\mathrm{C}+=$ positive control; $\mathrm{B}=$ negative control; $1 \mathrm{E}, 2 \mathrm{E}, 3 \mathrm{E}, 4 \mathrm{E}$ and $5 \mathrm{E}=$ samples. tissue (11). As the molecular analysis allowed a conclusive diagnosis no histological examination was performed for diagnostic purposes in the cases presented in this report.

Setting the diagnosis of FEH is extremely important because of the need for the differential diagnosis with other conditions, namely inflammatory fibrous hyperplasia, inflammatory papillary hyperplasia, verruciforme xanthoma, verrucous carcinoma, Cowden's disease, condyloma acuminatum, and focal dermal hypoplasia syndrome (Goltz-Gorlin syndrome) (2). The first three lesion types mentioned above are reactive lesions and, in most cases, an irritating agent can be identified. Verrucous carcinoma is a neoplasm that occurs in a different age group, with epidemiological features typically found in oral carcinomas. Cowden's disease, characteristic of an older age group, presents fibroepithelial polyps, which are more consistent, less mobile and have different intraoral topography.

A differential diagnosis with condyloma acuminatum is important because the clinical appearance of isolated lesions in both diseases is similar, as they are both caused by HPV. In spite of this, the patient's medical history is very helpful for differentiation, and FEH lesions tend to be flatter and more numerous. In addition, the location of FEH lesions (lip, tongue and buccal mucosa) is very characteristic.

PCR is a useful tool to identify the viral etiology of FEH lesions because it is a rapid and sensitive method (8). An additional advantage of PCR using consensus primers to HPV detection is the range of viral diversity that can be identified. Once the presence of HPV was detected in the cases presented in this paper, sequencing of PCR products was important to establish which viral type was actually the etiologic agent of FEH (in these cases, HPV-13). Thus, the differential diagnosis of condyloma acuminatum is rejected, as well as other papillomatous infections caused by HPV, such as laringeal papillomatosis (12). The molecular results are consistent with the epidemiological features of the patients, as well as with the clinical characteristics of the lesions.

Interestingly, none of the cases were positive for HPV-32 by DNA sequencing. HPV-32 is another type of HPV that causes FEH (5). No conclusions can be drawn about the prevalence of HPV-13 or -32 infection in the patients' community because only five cases have been studied.

FEH is described in the literature as a benign 
condition that heals spontaneously and therefore requires no treatment, except in some cases of functional (e.g., lesions that are constantly traumatized on biting) or aesthetic impairment (12). In the cases presented, all patients were treated. A 3-yer-old patient had habit of sucking the lesions and other patients had lesions that were constantly traumatized on biting. Several treatment modalities have been proposed for FEH, as scalpel surgery, cryotherapy, laser ablation, cauterization and topical treatments with retinoic acids or interferon (13). In the patients hereby described, topical treatments were excluded because the patients were not cooperative and compliant enough. Among the surgical treatments available in our service, cauterization was chosen because it presents lesser risks of bleeding and infection. Healing of all cases was uneventful. Follow-up of these patients is important for evaluation of treatment success. Likewise, epidemiological studies with the larger Indian groups are urged to know the exact prevalence of this disease among these populations, the long-term behavior of the lesions and the treatment protocols that might be required.

\section{RESUMO}

Hiperplasia epitelial focal ou doença de Heck é uma rara doença contagiosa causada pelos papilomavírus tipo 13 e 32 que foi inicialmente descrita entre populações nativas americanas. Esta doença caracteriza-se pela ocorrência de pequenas e múltiplas pápulas ou nódulos na cavidade bucal, especialmente nos lábios, mucosa bucal e língua. Este artigo descreve o diagnóstico da hiperplasia epitelial focal em cinco indígenas da Amazônia Central que procuraram tratamento na Fundação de Medicina Tropical do Amazonas (FMT-AM) utilizando critérios clínicos, reação em cadeia de polimerase (PCR) e sequenciamento de DNA

\section{REFERENCES}

1. Archard HO, Heck JW, Stanley HR. Focal epithelial hyperplasia: an unusual oral mucosal lesion found in Indian children. Oral Surg Oral Med Oral Pathol 1965;20:201-212.

2. Terezhalmy GT, Riley CK, Moore WS. Focal epithelial hyperplasia (Heck's disease). Quintessence Int 2001;32:664665 .

3. Jablonska S, Majewski S. Demonstration of HPV 24 in longstanding Heck's disease with malignant transformation. Eur J. Dermatol 2000;10:235-236.

4. Pfister H, Heltich J, Runne U, Chilf GN. Characterization of human papillomavirus type 13 from focal epithelial Heck lesions. J Virol 1983;47:363-366.

5. Beaudenon, S, Praetorius, F, Kremsdorf D, Lutzner M, Worsaae N, Pehau-Arnaudet G, Orth G. A new type of human papillomavirus associated with oral focal epithelial hyperplasia. J Invest Dermatol 1987;88:130-135.

6. Michael EJ, Husain S, Zalar G, Nuovo G. Focal epithelial hyperplasia in an Ecuadorian girl. Cutis 1999;64:395-396.

7. Pilgard G. Focal epithelial hyperplasia: report of nine cases from Sweden and review of the literature. Oral Surg Oral Med Oral Pathol 1984;57:540-543.

8. Bauer HM and Manos MM. PCR detection of genital human papillomavirus. In: Diagnostic Molecular Microbiology: Principles and Applications. Persing DH, Smith TF, Tenover FC, White JT (Editors). Washington, D.C.: American Society for Microbiology; 1993. p. 407-413.

9. van Ranst M, Fuse A, Fiten P, Beuken E, Pfister H, Burk RD, Opdenakker G. Human papillomavirus type 13 and pygmy chimpanzee papillomavirus type 1: comparison of the genome organizations. Virology 1992;190:587-596.

10. Harris AMP and Van Wyk CW. Heck's disease (focal epithelial hyperplasia: a longitudinal study. Community Dent Oral Epidemiol 1993;21:82-85.

11. Preatorius-Claussen F. Rare oral viral disorders (molluscum contagiosum, localized keratoacanthoma, verrucae, condyloma acuminatum, and focal epithelial hyperplasia). Oral Surg Oral Med Oral Pathol 1972;34:604-618.

12. Gross GE and Barrasso R (Editors). Human papilloma virus infection: a clinical atlas. Berlin: Ullstein Mosby; 1997.

13. Flaitz CM. Focal epithelial hyperplasia: A multifocal oral human papillomavirus infection. Pediatr Dent 2000;22:153154.

14. Papa MB, Cosigli JE, Maldonado SM, Chiappuis JM. Focal epithelial hyperplasia. Rev Arg Dermatol 1998;79:155-157.

Accepted September 6, 2005 